\title{
Consumers' characteristics and brand choice behaviour: Loyalty and consumption
}

Received (in revised form): 2nd March, 2007

\section{Rodolfo Vázquez Casielles}

is Professor of Marketing in the Department of Business Administration at the University of Oviedo, Spain. His research includes distribution channels, tourism marketing, industrial marketing, service quality, brand equity, relationship marketing and market orientation.

\section{Begoña Álvarez Álvarez \\ is Assistant Professor of Marketing in the Department of Business Administration at the University of Oviedo, Spain. Her research includes prices, reference prices, sales promotion, consumer behaviour and brand choice.}

Keywords level of consumption, loyalty, reference price, household panel, price

\begin{abstract}
The research described in this paper is intended to provide a deeper understanding of consumers' purchasing processes by describing a range of models that include the traditionally analysed variables of price, reference price and losses and gains and also by proposing two alternative ways to segment the market: by loyalty and by consumption levels. The key contributions of this research can be summarised under two points. First, it employs two different household panels to validate hypotheses and provide more reliable results, and secondly, it employs a market segment variable that is infrequently applied in this kind of work: consumption levels. Our results not only highlight the importance of the variables we propose but also point to the need to segment markets in line with a range of different criteria, given that both customer loyalty and consumption levels serve to show different purchasing patterns.

Journal of Targeting, Measurement and Analysis for Marketing (2007) 15, 121-133. doi:10.1057/palgrave.jt.5750034
\end{abstract}

\section{A CONCEPTUAL FRAMEWORK: BRAND CHOICE MODELS}

Manufacturers and retailers alike are keenly interested in understanding how a whole gamut of marketing variables, such as price, promotions and publicity, affect their sales and the market share of their products. This interest has spawned myriad studies, each of which sets out to uncover a behaviour 'pattern', that is, a model whereby the uncertainty surrounding the process of brand choice is lessened. The work of Guadagni and Little, ${ }^{1}$ who analysed the influence of loyalty,

Correspondence: Begoña Álvarez Álvarez, Facultad Ciencias Económicas y Empresariales, Avenida del Cristo s/n, Oviedo 33071, España.

Tel: + 34985106207 ;

Fax: + 349851037 08;

Email: mbalvarez@uniovi.es promotions and price-related factors on purchasing behaviour for coffee, figures prominently in the field. The work of Lattin and Bucklin $^{2}$ on how prices, brand preference and the presence or absence of promotion exerts an influence on coffee-brand choices is similarly relevant. Likewise, Kalyanaram and Little ${ }^{3}$ provided thorough research on how price variations affect consumer behaviour, focusing on sodas and alcoholic drinks in an attempt to define consumers' acceptable price range. Bell and Bucklin, ${ }^{4}$ for their part, analysed reference prices and previous experiences in the purchase of highfrequency products such as cookies and detergents, concluding that the actual price at the time of purchase, brand loyalty, the last brand that was purchased and reference price were the four outstanding variables in the process of brand 
choice. Finally, mention should be made of the work of Han et al., ${ }^{5}$ who estimate the effect of prices and of losses and gains on decisions to purchase.

\section{The influence of price at the time of purchase on brand choice}

Customer perception of price has interested researchers for many years, and the cascade of effects sparked off when a consumer observes prices has been central to much of the literature on the subject. It seems intuitively reasonable to consider price as a factor that reduces the uncertainty associated with purchasing. This occurs principally for products that are not well known to the customer or products that the customer has doubts about. It should, however, not be forgotten that price is not the only stimulus to which buyers respond. A whole gamut of theories on how consumers form an idea of the price they expect to pay has arisen in recent years $^{6-10}$ highlighting that both the price range the customer encounters at the time of purchase (henceforth referred to as 'observed price') and the price they actually pay have effects on later purchases. Consumers adapt themselves to prices, observe their fluctuations and behave accordingly.

The aim of this paper is to investigate whether price is a decisive variable in consumer behaviour and, if so, how it will consequently effect models of brand choice. This aim led to our first hypothesis:

$\mathbf{H}_{1}$ : The likelihood of purchasing one of a range of brands competing in a product category can be explained by price and its variations.

\section{The influence of reference price, losses and gains, on brand choice}

Reference price may be regarded as a subjective price level used by consumers to evaluate the price observed at the time of purchase. It is based upon consumers pricing by comparison, that is, they compare one price with others in order to know if a price is acceptable or not. Although there is a general agreement that reference prices play an important role in the process of brand choice, researchers fail to agree on how they are established, and provide contrasting explanations, which broadly fall into two categories. One the one hand, some claim that reference prices are established by the prices that the consumer has encountered on previous occasions; others, in contrast, consider that, since consumers generally have poor recall of past shopping experiences, they form their reference prices at the time of purchase by observing the prices of certain brands. Table 1 summarises these two approaches.

Losses and gains are a consequence of customer comparison of observed price and reference price. Customers will experience a loss when the observed price is higher than what they expect to pay. Conversely, they will experience a gain when observed price is lower than expected price. Explicit consideration of these two phenomena in brand choice models will provide a better understanding of consumer behaviour. It is generally assumed that losses will reduce the probability of making a choice, while gains will foster purchase of the brand. The intensity of the effect of gains and losses on brand choice, however, differs, as there are asymmetric effects. There is no unanimous agreement as to which is the more powerful. Hardie et al. ${ }^{11}$ contend that the loss-generated reduction in utility is greater than its gain-generated increment, that is consumers tend to be reluctant to take on losses and, as a result, will react more strongly to losses than gains. Briesch et al., ${ }^{12}$ however, provide empirical evidence of quite the opposite response to gains is stronger than response to losses - arguing that gains prompt consumers to increase their purchase volume to take advantage of price. Furthermore, loyal consumers will continue to buy their favourite brand even when they perceive losses.

This work presents the following initial hypothesis:

$\mathbf{H}_{2}$ : The effect caused by losses on the likelihood of choosing a specific brand has a different intensity than the effect caused by gains. 
Table 1: Reference prices models used in past research

\begin{tabular}{l}
\hline Model descriptions \\
Reference prices by stimulus or observation \\
Random brand's current price \\
The consumer not only has no knowledge of brand prices but \\
also is unable to determine which brand's current price should \\
be used to compare price of other brands. The consumer may \\
randomly select a brand available on the current purchase \\
occasion and use this price as a reference point for price \\
judgments.
\end{tabular}

Reference brand's current Price

The consumer cannot remember the paid price but does have a reference brand (eg the brand chosen on last occasion) in memory. When evaluating prices of other brands, the consumer, therefore, uses the current price of this brand for comparing prices of all other brands.

Reference prices based on past prices (memory)

Prices of previously chosen brands

Consumers are believed to have a stronger memory for attribute information of the chosen brand than for the rejected brand. The price of the brand previously chosen, rather than prices of all brands encountered, during past purchase occasions should be readily accessible in consumer memory and used as a common reference point for comparing the current prices.

Brand specific past prices

Consumers are able to distinguish among the prices of different brands encountered during past purchase occasions. The reference price is unique for each brand and it is the result of the own brand price history. The reference price effect is therefore temporal.

Brand specific past prices and other information The consumers not only remember specific prices of each brand but they also use other information such as price trend and frequency of deals for each brand.
Models and variables

$$
R P_{h t}=S P_{h(r b[t]) t}
$$

$R P_{h t}$ : the reference price of household $h$ on occasion $t$; $S P_{h(r b[t]) t}$ : the self price from the brand select randomly for household $h$ on occasion $t$.

$$
R P_{h t}=S P_{h(c b[t-1]) t}
$$

$R P_{h t}:$ the reference price of household $h$ on occasion $t$; $S P_{h(c b[t-1]) t}$ the self price of the reference brand for household $h$ on occasion $t$.

$$
R P_{h t}=\alpha R P_{h(t-1)}+(1-\alpha) S P_{h(c b[t-1])(t-1)}
$$

$R P_{h t}:$ the reference price of household $h$ on occasion $t$; $R P_{h(t-1)}$ : the reference price of household $h$ on occasion $t$; $S P_{h(c b[t-1])(t-1)}$ : the price of the reference brands chose for the household $h$ on past occasions; $\alpha$ : carryover weight.

$$
R P_{h j t}=\alpha R P_{h j(t-1)}+(1-\alpha) S P_{h j(t-1)}
$$

$R P_{h j t}$ : the reference price of household $h$ for brand $j$ on occasion $t ; R P_{h j(t-1)}$ : the reference price of household $h$ for the brand $j$ on occasion $t-1 ; S P_{h j(t-1)}$ : the price of brand $j$ on past occasions; $\alpha$ : carryover weight.

$R P_{h j t}=\gamma_{0}+\gamma_{1} S P_{h j(t-1)}+\gamma_{2} T R E N D_{j t}+\gamma_{3} D P_{h t}+\gamma_{4} D F_{j t}+\varepsilon_{h j t}$

$R P_{h j t}$ : the reference price of household $h$ for brand $j$ on occasion $t ; S P_{h(t-1)}$ : the reference price of household $h$ for the brand $j$ on occasion $t-1$; TREND $D_{j t}$ : price trend of brand $j$ until occasion $t-1 ; D P_{j t}$ : deal proneness of household $h$ until occasion $t ; D F_{j t}$ : frequency of promotion of brand $j$ until occasion $t$.
Having established this point, this study will then proceed to determine which of the two effects exerts a greater influence on the probability of choosing one brand in preference to another.

\section{MARKET SEGMENTATION AND THE PROCESS OF BRAND CHOICE}

A range of variables have been incorporated into brand choice models in an attempt to tease out the factors responsible for different consumer responses. The 'purchase model' developed by Krishnamurthi et al. ${ }^{13}$ focuses upon consumer loyalty to analyse different response to loss and gain. Simonson and Winer ${ }^{14}$ explain differences in the brand choice process in terms of the quantity of the product purchased. The use of demographic and psychographic variables has also been useful to estimate the preference of consumers for distributors' brands and promotions. ${ }^{15}$ Taking this and other research as a starting point, this paper focuses on the effect of two segmentation variables on the process of brand choice: loyalty and consumption level. 


\section{Loyalty and brand choice}

Consumer loyalty is a key factor in the study of brand choice, and its influence on the perception and employment of reference prices and on reactions to losses and gains has been studied in numerous articles (for example, Mazumdar and Papatla, ${ }^{16}$ Bell and Bucklin, ${ }^{17}$ Briesch et al., ${ }^{18}$ Krishnamurthi et al., ${ }^{19}$ Krishnamurthi and $\mathrm{Raj}^{20}$ ). Two points need to be considered as regards its influence on the response to losses and gains: First, loyal consumers may possibly respond with more intensity to gains than to losses, since when the price of frequently purchased products or brands goes up, consumers will continue to buy them. Inversely, when prices fall, consumers perceive a gain and purchase a larger quantity of the product. ${ }^{21}$ Secondly, arguments to the effect that nonloyal consumers will respond more to gains have been propounded. Loyal consumers may be insensitive to price changes of their favourite brand. Response is therefore asymmetric, depending on customer loyalty.

The above authors claim that consumers who switch between brands will be more sensitive to gains rather than to losses, which implies that they are guided by the desire to obtain a reduction in price, rather than by a desire to avoid paying more than usual for the product. They like to know that they have obtained a 'bargain' and that they have exploited a good opportunity. Such nonloyal consumers may respond with more intensity to gains, since gains are often the outcome of coupons or direct price cuts, which are usually heavily advertised and publicised, thanks to which consumers are more aware of gains than losses. A further aim of this paper is to demonstrate that there are different behaviours in the process of brand choice that depend on the consumers' characteristics. Customers will be divided into loyal and nonloyal categories, and the following hypothesis is proposed:

$\mathbf{H}_{3}$ : The brand choice selection process depends on the level of consumers' loyalty.
$\mathbf{H}_{3 \mathbf{a}}$ : Sensitivity to losses and gains changes depending on whether the consumer is loyal or not.

\section{Consumption level and brand choice}

The relationship between consumption level and brand choice has attracted little attention, although Simonson and Winer ${ }^{22}$ or Vázquez et al., ${ }^{23}$ have highlighted its importance. We might intuitively assume that households with high consumption of a certain product category will exhibit different purchasing behaviour to households that have lower consumption. When a household regularly acquires a certain product category, it may well be more sensitive and concerned about the price than families who consume less of the same product. As the latter only acquire the product on rare occasions, they can 'afford' to pay a higher price for it. This behavioural distinction can be used as a comparative element of quality. The corollary is also true: when there is a minimal frequency of product acquisition, the way reference prices are arrived at may be affected. There might be a stronger influence of observed prices at the time of purchase because the consumer does not remember the prices paid on previous occasions. In consequence, consumption level is a variable that can help to segment the market, and in consequence, the following hypothesis is proposed:

$\mathbf{H}_{4}$ : Brand choice behaviour differs according to a household's consumption level.

\section{THE RESEARCH METHODOLOGY}

There are undoubtedly a whole gamut of variables that affect brand choice decision-taking, some of which - for example, the importance of prices, reference prices and losses and gains have been so thoroughly researched as to become accepted as proven. This paper will take those same concepts and will attempt to analyse and measure their effects on consumer behaviour in the light of two key factors of market 
segmentation: loyalty and consumption level (cf Figure 1).

The process of consumer choice can be analysed in line with the proposals of Guadagni and Little ${ }^{24}$ and Kamakura and Russell ${ }^{25}$ as follows: when a consumer faces a decision to purchase, he assigns a utility to each of the available alternatives, opting finally for the one that provides her with greater utility. There are two components to this utility function (one deterministic, represented by $V_{i h t}$, and one random, represented by $\left.e_{i h t}\right)$ This is reflected in the expression:

$$
\begin{gathered}
U_{i h t}=V_{i h t}+e_{i h t} \\
V_{i h t}=\beta_{0 i}+\sum_{P=1}^{z} \beta_{P} . V M_{i h t}^{P}
\end{gathered}
$$

where $U_{\text {iht }}$ is the utility of brand $i(i=1,2,3, \ldots$, I) to household $h(h=1,2,3, \ldots, H)$ at purchase occasion $t(t=1,2,3, \ldots, T) ; V_{\text {iht }}$ the deterministic component of the utility. It will depend on the perception that the consumer has of the attributes

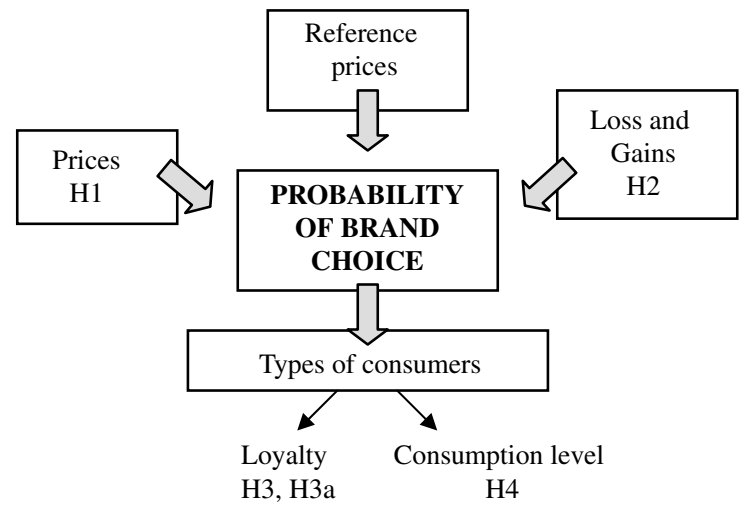

Figure 1: Structure of the study of the brand and of the different marketing variables that are applied on this brand; $V M_{i h t}$ Pthe value of marketing variable $P(P=1, \ldots, z)$ for brand $i$ to household $h$ at purchase occasion $t ; \beta_{0 i}$ the specific coefficients for each brand; $\beta_{P}$ the coefficients for marketing variables; $e_{i h t}$ the random error of the household $h$ in the utility of brand $i$ at purchase occasion $t$.

\section{Characteristics of the sample}

As Table 2 shows, the present study employed both a national household panel provided by the Taylor Nelson Sofres Group and a regional household panel, which served as a contrast for the results that were obtained.

Margarine, the market for which is dominated by a handful of brands and which is a good example of a frequently purchased product, was selected for the present study, which is part of a larger study that also encompasses other product categories. The results of this larger macro-study will not be presented here for reasons of brevity and because results are mirrored across categories. The four brands with the highest market share in each of the household panels, one of which was an own label brand, were selected.

To reach the objectives proposed in the study, the logit multinomial models were applied as the most appropriate for this type of study. In these models, a dependent variable is used with several categories, in our case the margarine brands available on the market. The independent variables reflect characteristics relative to the purchase carried out by each consumer, in our case: prices, losses and gains, loyalty and consumption level.

Table 2: Characteristics of the panel data

\begin{tabular}{lll}
\hline Characteristics & $\begin{array}{l}\text { National consumers panel } \\
\text { (Taylor Nelson Sofres panel) }\end{array}$ & $\begin{array}{l}\text { Regional consumers panel } \\
\text { (own elaboration) }\end{array}$ \\
\hline Scope & National & Regional \\
Period & 1 year & 1 year \\
Studied products & 20 categories of product & 54 categories of product \\
Selected product & Margarine & Margarine \\
Purchase occasions & 5,900 & 711 \\
Brands & 4 & 4 \\
Sizes & $250 \mathrm{~g} / 500 \mathrm{~g}$ & $250 \mathrm{~g} / 500 \mathrm{~g}$ \\
\hline
\end{tabular}


Table 3: Different estimates of reference prices

Reference prices by stimuli or observation
- The individual takes as reference price the price of
any other of the brands that are in the market at the
moment of the purchase.
- The reference price is calculated as the arithmetic
mean between the highest price and the lowest
one of the brands in the market at the moment of
purchase.
Reference prices starting from passed purchase
experiences
The reference price is calculated as the price paid
by the individual the last time that he/she bought the
same brand that he/she will acquire at the moment of
the purchase.
The reference price is the price paid the last time
the person bought the same category of products,
independently of the brand that was acquired.
The reference price is calculated as an exponentially
smoothed composite of the prices of a brand faced
by a consumer during his entire purchase history. In
this research, a coefficient of 0.2 is used.

\section{RESULTS}

\section{Effect of prices, losses and gains on brand choice}

Estimating reference prices was necessary to test the proposed hypotheses. Earlier research, incorporating five different estimates of price reference, was carried out to determine the best way to do this (Table 3).

Our results ${ }^{26}$ indicate that the best approach to reference prices is based on prices observed at the time of purchase, that is, the arithmetic average of the highest and lowest market price for the category of products purchased. This estimate is the basis for calculating losses and gains included in the choice models proposed below. The following model is proposed for checking the effect of prices, losses and gains on the likelihood of making a particular brand choice:

$$
\begin{aligned}
& U_{i h t}=V_{i h t}+e_{i h t}=\beta_{0 i}+\beta_{P} P_{i h t}+\beta_{\text {LOSS }} L_{\text {OSS }} \text { iht } \\
& +\beta_{\text {GAIN }} \text { GAIN }_{\text {iht }}+e_{i h t} \\
& \operatorname{LOSS}_{i h t}=P\left(P_{i h t}-P R_{h t}\right) \\
& \operatorname{GAIN}_{\text {iht }}=G\left(P R_{h t}-P_{i h t}\right)
\end{aligned}
$$

where $U_{i h t}$ is the utility of brand $i$ to household $h$ at purchase occasion $t ; P_{i h t}$ the price of brand $i$ for household $h$ at purchase occasion $t ; P R_{h t}$ the reference price for household $h$ at purchase occasion $t$; LOSS iht the difference when reference price is lower than price of brand $i$ for household $h$ at the purchase occasion $h$; GAIN $N_{i h t}$ the difference when reference price is higher than price of brand $i$ for household $h$ at the purchase occasion $h$; $L$ the dummy variable: $P=0$ if $P_{\text {iht }}<P R_{h t}, P=1$ if $P_{\text {iht }}>P R_{h t}$; $G$ the dummy variable: $G=0$ if $P_{i h t}>P R_{h t}, G=1$ if $P_{i h t}<P R_{h t} ; e_{i h t}$ the random error of the household $h$ in the utility of brand $i$ at the purchase occasion $t ; \beta_{0 i}$ the specific coefficients for each brand; $\beta_{B} \beta_{L O S S}$, $\beta_{\mathrm{GAIN}}$ the coefficients for price, losses and gains.

This model has been estimated for the selected product category (margarine) using the two panels explained in a previous section of this study. Table 4 summarises the results obtained.

As Table 4 shows, the 'price' variable influences brand choice. Both the national and regional panels point to price being a significant variable for each of the brands considered, as well as for the overall model. Therefore, as proposed in $\mathrm{H}_{1}$, it can be concluded that price plays a part in explaining brand choice.

Having established the influence of this variable, the following aim is to analyse the effect of losses and gains. To study the asymmetric effects of losses and gains, the value of $\exp (\beta)$ for losses and gains must be analysed. This value gives the marginal effect produced by the increment in a monetary unit of the losses or gains, respectively. To check the magnitude of the marginal change, $/ 1-\operatorname{Exp}(b) /$ is calculated for each of the brands in both variables, thereby enabling a quantification of consumer response to be made (cf Table 5).

The marginal effect produced as a consequence of a change in the losses versus gains is of different intensity. If we consider the national panel for brand B1, an increment in the gains in a monetary unit means a change in the absolute value of brand choice probability of 0.011 $(|1-0.989|)$. The increment in the loss in a monetary unit involves a change in absolute value of $0.059(|1-1.059|)$. As this same phenomenon occurs across brands, we can conclude that the effect of losses and gains are of different intensities. If results from applying the model to 
Table 4: Brand choice for the national and the regional panel (price, losses and gains)

\begin{tabular}{|c|c|c|c|c|c|c|c|c|c|}
\hline \multirow[t]{2}{*}{ Variables } & \multicolumn{2}{|l|}{ Brand BO } & \multicolumn{2}{|l|}{ Brand B1 } & \multicolumn{2}{|l|}{ Brand B2 } & \multirow{2}{*}{$\begin{array}{l}\text { Global } \\
\text { signifi- } \\
\text { cance }\end{array}$} & \multirow{2}{*}{\multicolumn{2}{|c|}{$\begin{array}{l}\text { Indicators of the model } \\
\text { adjustment }\end{array}$}} \\
\hline & $Z$ & $\operatorname{Exp}(\beta)$ & $Z$ & $\operatorname{Exp}(\beta)$ & $Z$ & $\operatorname{Exp}(\beta)$ & & & \\
\hline \multicolumn{10}{|c|}{ National panel } \\
\hline Price & $\begin{array}{r}-14.335 \\
(0.000)\end{array}$ & 0.802 & $\begin{array}{c}20.222 \\
(0.000)\end{array}$ & 1.062 & $\begin{array}{c}6.960 \\
(0.000)\end{array}$ & 1.021 & $\begin{array}{r}3021.908 \\
(0.000)\end{array}$ & $\begin{array}{l}\mathrm{LL}(\mathrm{c}) \\
\mathrm{LL}(\beta)\end{array}$ & $\begin{array}{l}-7984.1534 \\
-4709.4618\end{array}$ \\
\hline Gains & $\begin{array}{c}1.527 \\
(0.000)\end{array}$ & 1.021 & $\begin{array}{r}-3.978 \\
(0.000)\end{array}$ & 0.989 & $\begin{array}{r}-10.366 \\
(0.000)\end{array}$ & 0.964 & $\begin{array}{r}146.346 \\
(0.000)\end{array}$ & $\begin{array}{l}\text { Test RV } \\
\text { Rho }^{2}\end{array}$ & $\begin{array}{c}6549.3832 \text { (9 g.l.) } \\
0.4101\end{array}$ \\
\hline Losses & $\begin{array}{c}5.948 \\
(0.000)\end{array}$ & 1.277 & $\begin{array}{l}11.396 \\
(0.000)\end{array}$ & 1.059 & $\begin{array}{c}10.615 \\
(0.000)\end{array}$ & 1.055 & $\begin{array}{r}174.017 \\
(0.000)\end{array}$ & $\begin{array}{l}\text { Rho }^{2} \text { aj. } \\
\text { AIC }\end{array}$ & $\begin{array}{r}0.4090 \\
4718.4618\end{array}$ \\
\hline Constant & $\begin{array}{l}11.326 \\
(0.000)\end{array}$ & & $\begin{array}{r}-23.640 \\
(0.000)\end{array}$ & & $\begin{array}{r}-8.803 \\
(0.000)\end{array}$ & & & $\begin{array}{l}\text { CAIC } \\
\text { SBIC }\end{array}$ & $\begin{array}{l}9506.0680 \\
9497.0680\end{array}$ \\
\hline \multicolumn{10}{|c|}{ Regional panel } \\
\hline Price & $\begin{array}{r}-8.227 \\
(0.000)\end{array}$ & 0.938 & $\begin{array}{c}4.632 \\
(0.000)\end{array}$ & 1.027 & $\begin{array}{r}-3.189 \\
(0.001)\end{array}$ & 0.984 & $\begin{array}{r}150.335 \\
(0.000)\end{array}$ & $\begin{array}{l}\mathrm{LL}(\mathrm{c}) \\
\mathrm{LL}(\beta)\end{array}$ & $\begin{array}{l}-906.0526 \\
-760.4027\end{array}$ \\
\hline Gains & $\begin{array}{c}5.149 \\
(0.000)\end{array}$ & 1.053 & $\begin{array}{r}-0.217 \\
(0.828)\end{array}$ & 0.998 & $\begin{array}{c}0.195 \\
(0.845)\end{array}$ & 1.002 & $\begin{array}{c}31.472 \\
(0.000)\end{array}$ & $\begin{array}{l}\text { Test RV } \\
\text { Rho }^{2}\end{array}$ & $\begin{array}{c}305.6629 \text { (9 g.l.) } \\
0.1687\end{array}$ \\
\hline Losses & $\begin{array}{c}3.758 \\
(0.000)\end{array}$ & 1.059 & $\begin{array}{r}-3.460 \\
(0.001)\end{array}$ & 0.966 & $\begin{array}{r}-2.534 \\
(0.011)\end{array}$ & 0.977 & $\begin{array}{c}34.270 \\
(0.000)\end{array}$ & $\begin{array}{l}\text { Rho }^{2} \text { aj. } \\
\text { AIC }\end{array}$ & $\begin{array}{r}0.1587 \\
762.2212\end{array}$ \\
\hline Constant & $\begin{array}{c}5.211 \\
(0.000)\end{array}$ & & $\begin{array}{r}-5.806 \\
(0.000)\end{array}$ & & $\begin{array}{c}2.782 \\
(0.005)\end{array}$ & & & $\begin{array}{l}\text { CAIC } \\
\text { SBIC }\end{array}$ & $\begin{array}{l}1574.5424 \\
1565.5424\end{array}$ \\
\hline
\end{tabular}

Brand 0: private brand. Brand 1, 2: brand with smaller share market than brand 3. Brand 3: leader brand is taken as a reference in the analysis.

$\chi_{\mathrm{c}, 9,95 \%}{ }^{2}=16.9$.

Table 5: Marginal effect of the change in prices, losses and gains $(|1-\operatorname{Exp}(B)|)$

\begin{tabular}{|c|c|c|c|c|c|c|}
\hline \multirow[b]{2}{*}{ Variables } & \multicolumn{3}{|c|}{ National panel } & \multicolumn{3}{|c|}{ Regional panel } \\
\hline & Brand BO & Brand B1 & Brand B2 & Brand BO & Brand B1 & Brand B2 \\
\hline Price & 0.198 & 0.062 & 0.021 & 0.062 & 0.027 & 0.016 \\
\hline Gains & 0.021 & 0.011 & 0.036 & 0.053 & 0.002 & 0.002 \\
\hline Losses & 0.277 & 0.059 & 0.055 & 0.059 & 0.034 & 0.023 \\
\hline
\end{tabular}

the regional panel are now analysed, the conclusion is the same, thereby confirming $\mathrm{H}_{2}$ : there are asymmetric effects between losses and gains.

The 'direction' of this differing intensity, that is, whether the gain effect is stronger or weaker than the loss effect, can be calculated by analysing the results obtained in greater depth. As was previously pointed out, there is no consensus among researchers on this question. Results for the national panel show that the effect of increments in the losses exceeds the effect of the same increment in the gains across the board for all brands. Therefore, in these results, there is unanimity in the direction of intensity. The regional panel points to a similar situation: intensity of losses involves greater variation in choice probability than that caused by the gains. In fact, gains do not cause significant variations in choice probability for two of the brands, while the effect of losses for these same brands is significant. This analysis seems to indicate that the effect of losses on brand choice exceeds the effect of gains, which is in tune with the conclusions reached in such studies as Bell and Bucklin $^{27}$ and Hardie et al. ${ }^{28}$ Nevertheless, it must be pointed out that the results might vary according to both product and consumer characteristics.

\section{Effect of consumer loyalty on brand choice}

A more thorough understanding of the process of consumer brand choice requires the market to be 
segmented. Loyalty influences this process and affects the consumers' sensitivity to prices, to reference prices and to losses and gains.

The first issue to be clarified in this study is whether brand choice behaviours vary as a function of customer loyalty. This can be done by dividing the group of consumers into loyal and nonloyal and applying the index $L_{i h}$, which is defined as the quotient of the number of times the consumer has bought brand $i$, divided by the total number of purchase occasions for the group of brands in the product category, that is:

$$
L_{i h}=\frac{n_{i h}}{N_{h}}
$$

where $n_{i h}$ is the purchase occasions in which household $h$ has acquired brand $i ; N_{h}$ the purchase occasions for household $h ; L_{i h}$ the loyalty of household $h$ to brand $i$.

Work by the likes of Mazumdar and Papatla ${ }^{6,16}$ set household loyalty levels for brand purchase at above 60 per cent of purchasing opportunities. We, however, increased this threshold to 85 per cent in order to establish loyal and nonloyal household groups of approximately similar sizes. Panel segmentation came out as follows: for the national panel, loyal and nonloyal groups represent 59.92 and 40.08 per cent of the total sample, respectively. The equivalent percentages for the regional panel were 41.37 and 58.63 per cent.

The objective of the analysis was to confirm whether establishing two groups of consumers with different behaviours is acceptable in terms of statistics. Chapman and Staelin, ${ }^{29}$ Gensch $^{30,31}$ and Gensch and Javalgi ${ }^{32}$ carried out research in this field, dividing the initial sample into small groups and applying the following equation:

$$
2\left\{L L\left(\beta^{T}\right)-\left[L L\left(\beta^{1}\right)+L L\left(\beta^{2}\right)\right]\right\}
$$

where $L L(\beta \mathrm{T})$ is the likelihood function for all household of the sample; $L L\left(\beta^{1}\right), L L\left(\beta^{2}\right)$ the likelihood function for each one of the considered groups.
This expression follows a chi-square distribution with $k$ degrees of freedom, where $k$ is the number of categories of the dependent variable minus one multiplied by the number of parameters to be estimated.

Two segments were identified, one of them formed by the loyal households and the other one by the nonloyal households. Model (2) was used to carry out a comparison. Table 6 summarises the national and regional panel results in the application of the selection model for both consumer segments.

The equation used to demonstrate that there are two groups of consumers with different bahaviour patterns clearly exceeds the critical limit for a significance level of 0.05 , which means that the null hypothesis of homogeneity in the logit function can be rejected. In consequence, it can be stated that groups established according to household loyalty have coefficients that are statistically different (hypothesis 3 ). As both panels coincide, the consistency of these results is confirmed, thereby demonstrating that there are two consumer groups whose reactions, purchase behaviour patterns and probable brand choice differ substantially.

To check which of the two effects (losses or gains) is stronger for loyal and nonloyal consumers, we observed the marginal effect of losses and gains in both segments and for the two panels. Since it is not possible to compare the value of the coefficients in models that come from different samples, we first attempted to discover if the losses are bigger than the gains within each of the segments. Applying the model to the group of loyal households of the national panel shows that the losses effect is greater than the gains effect. The same results are found for the nonloyal households. In both cases, therefore, the response to losses is more intense than to gains.

When the regional panel was studied, the response of the group of loyal households to losses is also stronger. Losses are, however, not significant for the group of nonloyal households, being either irrelevant in the model or failing to add new information. The explanation of this fact could be the following: 
Table 6: Model of brand choice for loyal and nonloyal group

\begin{tabular}{|c|c|c|c|c|c|c|c|c|c|}
\hline \multirow[t]{2}{*}{ Variables } & \multicolumn{2}{|l|}{ Brand BO } & \multicolumn{2}{|l|}{ Brand B1 } & \multicolumn{2}{|c|}{ Brand B2 } & \multirow{2}{*}{$\begin{array}{l}\text { Global } \\
\text { signification }\end{array}$} & \multirow{2}{*}{\multicolumn{2}{|c|}{$\begin{array}{l}\text { Indicators of the model } \\
\text { adjustment }\end{array}$}} \\
\hline & $Z$ & $\begin{array}{l}\operatorname{Exp} \\
(\beta) / 1-\operatorname{Exp}(\beta) /\end{array}$ & $Z$ & $\begin{array}{l}\operatorname{Exp} \\
(\beta) / 1-\operatorname{Exp}(\beta) /\end{array}$ & $Z$ & $\begin{array}{l}\operatorname{Exp} \\
(\beta) / 1-\operatorname{Exp}(\beta) /\end{array}$ & & & \\
\hline \multicolumn{10}{|c|}{$\begin{array}{l}\text { National panel } \\
\text { Loyal group }\end{array}$} \\
\hline \multirow[t]{2}{*}{ Price } & -10.141 & 0.789 & 16.544 & 1.071 & 3.696 & 1.015 & 1918.087 & $\mathrm{LL}(\mathrm{c})$ & -4787.9339 \\
\hline & $(0.000)$ & 0.211 & $(0.000)$ & 0.071 & $(0.000)$ & 0.015 & $(0.000)$ & $\mathrm{LL}(\beta)$ & -2630.372 \\
\hline \multirow[t]{2}{*}{ Gains } & 0.575 & 1.011 & -2.163 & 0.992 & -8.753 & 0.957 & 112.917 & Test RV & 4315.1238 (9 g.l.) \\
\hline & $(0.565)$ & 0.011 & (0.031) & 0.008 & $(0.000)$ & 0.043 & $(0.000)$ & $\mathrm{Rho}^{2}$ & 0.4506 \\
\hline \multirow[t]{2}{*}{ Losses } & 6.215 & 1.341 & 9.322 & 1.065 & 10.043 & 1.070 & 143.217 & Rho²aj. & 0.4487 \\
\hline & $(0.000)$ & 0.341 & $(0.000)$ & 0.065 & $(0.000)$ & 0.070 & $(0.000)$ & $\mathrm{AIC}$ & 2639.372 \\
\hline \multirow[t]{2}{*}{ Constant } & 8.144 & & -19.319 & & -4.996 & & & CAIC & 5343.2782 \\
\hline & $(0.000)$ & & $(0.000)$ & & $(0.000)$ & & & SBIC & 5334.2782 \\
\hline \multicolumn{10}{|c|}{ Nonloyal group } \\
\hline \multirow[t]{2}{*}{ Price } & -10.264 & 0.813 & 12.189 & 1.054 & 6.294 & 1.028 & 1123.963 & $\mathrm{LL}(\mathrm{c})$ & -3164.0044 \\
\hline & $(0.000)$ & 0.187 & $(0.000)$ & 0.054 & $(0.000)$ & 0.028 & $(0.000)$ & $\operatorname{LL}(\beta)$ & -2019.6853 \\
\hline \multirow[t]{2}{*}{ Gains } & 1.585 & 1.028 & -3.175 & 0.986 & -5.658 & 0.972 & 42.958 & Test RV & 2288.6382 (9 g.l.) \\
\hline & $(0.113)$ & 0.028 & $(0.001)$ & 0.014 & $(0.000)$ & 0.028 & $(0.000)$ & $\mathrm{Rho}^{2}$ & 0.3617 \\
\hline Losses & $\begin{array}{c}0.795 \\
(0.427)\end{array}$ & $\begin{array}{l}1.115 \\
0.115\end{array}$ & $\begin{array}{c}6.591 \\
(0.000)\end{array}$ & $\begin{array}{l}1.051 \\
0.051\end{array}$ & $\begin{array}{l}3.944 \\
(0.000)\end{array}$ & $\begin{array}{c}1.032 \\
0.032\end{array}$ & $\begin{array}{c}47.323 \\
(0.000)\end{array}$ & $\begin{array}{l}\text { Rho }^{2} \text { aj. } \\
\text { AIC }\end{array}$ & $\begin{array}{r}0.3588 \\
2028.6853\end{array}$ \\
\hline Constant & $\begin{array}{c}8.139 \\
(0.000)\end{array}$ & & $\begin{array}{r}-14.134 \\
(0.000)\end{array}$ & & $\begin{array}{r}-7.565 \\
(0.000)\end{array}$ & & & $\begin{array}{l}\text { CAIC } \\
\text { SBIC }\end{array}$ & $\begin{array}{l}4118.2874 \\
4109.2874\end{array}$ \\
\hline \multicolumn{10}{|c|}{$-2\left\{\mathrm{LL}\left(\beta^{\top}\right)-\left[\mathrm{LL}\left(\beta^{\mathrm{L}}\right)+\mathrm{LL}\left(\beta^{\mathrm{NL}}\right)\right]\right\}=118.809$ (9 g.l. $)$} \\
\hline \multicolumn{10}{|c|}{ Regional panel } \\
\hline Price & $\begin{array}{l}-5.643 \\
(0.000)\end{array}$ & $\begin{array}{l}0.945 \\
0.055\end{array}$ & $\begin{array}{c}4.914 \\
(0.000)\end{array}$ & $\begin{array}{l}1.041 \\
0.041\end{array}$ & $\begin{array}{r}-3.020 \\
(0.003)\end{array}$ & $\begin{array}{l}0.980 \\
0.020\end{array}$ & $\begin{array}{c}96.539 \\
(0.000)\end{array}$ & $\begin{array}{l}\mathrm{LL}(c) \\
\mathrm{LL}(\beta)\end{array}$ & $\begin{array}{l}-518.4963 \\
-411.8256\end{array}$ \\
\hline Gains & $\begin{array}{c}4.553 \\
(0.000)\end{array}$ & $\begin{array}{l}1.070 \\
0.070\end{array}$ & $\begin{array}{r}-0.623 \\
(0.534)\end{array}$ & $\begin{array}{l}0.992 \\
0.008\end{array}$ & $\begin{array}{r}-1.910 \\
(0.056)\end{array}$ & $\begin{array}{l}0.979 \\
0.021\end{array}$ & $\begin{array}{c}37.726 \\
(0.000)\end{array}$ & $\begin{array}{l}\text { Test RV } \\
\text { Rho }^{2}\end{array}$ & $\begin{array}{c}213.3414 \text { (9 g.l.) } \\
0.2057\end{array}$ \\
\hline Losses & $\begin{array}{c}4.243 \\
(0.000)\end{array}$ & $\begin{array}{l}1.092 \\
0.092\end{array}$ & $\begin{array}{r}-3.909 \\
(0.000)\end{array}$ & $\begin{array}{l}0.945 \\
0.055\end{array}$ & $\begin{array}{r}-2.831 \\
(0.005)\end{array}$ & $\begin{array}{l}0.967 \\
0.033\end{array}$ & $\begin{array}{c}47.588 \\
(0.000)\end{array}$ & $\begin{array}{l}\mathrm{Rho}^{2} \text { aj. } \\
\mathrm{AIC}\end{array}$ & $\begin{array}{r}0.1884 \\
420.8256\end{array}$ \\
\hline Constant & $\begin{array}{c}2.104 \\
(0.035)\end{array}$ & & $\begin{array}{r}-5.718 \\
(0.000)\end{array}$ & & $\begin{array}{l}2.976 \\
(0.003)\end{array}$ & & & $\begin{array}{l}\text { CAIC } \\
\text { SBIC }\end{array}$ & $\begin{array}{l}886.9920 \\
877.9920\end{array}$ \\
\hline \multicolumn{10}{|c|}{ Nonloyal group } \\
\hline Price & $\begin{array}{r}-6.035 \\
(0.000)\end{array}$ & $\begin{array}{l}0.929 \\
0.071\end{array}$ & $\begin{array}{c}1.112 \\
(0.266)\end{array}$ & $\begin{array}{l}1.010 \\
0.010\end{array}$ & $\begin{array}{r}-1.811 \\
(0.070)\end{array}$ & $\begin{array}{l}0.986 \\
0.014\end{array}$ & $\begin{array}{c}65.899 \\
(0.000)\end{array}$ & $\begin{array}{l}\mathrm{LL}(c) \\
\mathrm{LL}(\beta)\end{array}$ & $\begin{array}{l}-384.7422 \\
-322.4606\end{array}$ \\
\hline Gains & $\begin{array}{c}2.992 \\
(0.003)\end{array}$ & $\begin{array}{l}1.050 \\
0.050\end{array}$ & $\begin{array}{c}0.475 \\
(0.635)\end{array}$ & $\begin{array}{l}1.007 \\
0.007\end{array}$ & $\begin{array}{c}2.211 \\
(0.027)\end{array}$ & $\begin{array}{l}1.027 \\
0.027\end{array}$ & $\begin{array}{c}10.844 \\
(0.013)\end{array}$ & $\begin{array}{l}\text { Test RV } \\
\text { Rho }^{2}\end{array}$ & $\begin{array}{c}124.5631 \text { (9 g.l.) } \\
0.1619\end{array}$ \\
\hline \multirow[t]{2}{*}{ Losses } & 0.540 & 1.020 & -0.409 & 0.994 & -0.552 & 0.009 & 0.767 & Rho²aj. & 0.1385 \\
\hline & $(0.589)$ & 0.020 & $(0.682)$ & 0.006 & $(0.581)$ & 0.991 & $(0.857)$ & $\mathrm{AIC}$ & 331.4606 \\
\hline \multirow[t]{2}{*}{ Constant } & 4.747 & & -1.932 & & & & & CAIC & 705.0120 \\
\hline & $(0.000)$ & & $(0.053)$ & & & & & SBIC & 696.0120 \\
\hline$-2\left\{\operatorname{LL}\left(\beta^{\top}\right)-\right.$ & $\mathrm{LL}\left(\beta^{\mathrm{L}}\right)+\mathrm{LL}\left(\beta^{\mathrm{N}}\right.$ & L)]\}=37.8699 $(9 \mathrm{~g}$ & .I.) & & & & & & \\
\hline
\end{tabular}

$\mathrm{LL}\left(\beta^{\top}\right)$ : sample likelihood function.

$\operatorname{LL}\left(\beta^{\mathrm{L}}\right)$ : Loyal group likelihood function.

$\operatorname{LL}\left(\beta^{\mathrm{NL}}\right)$ : Nonloyal group likelihood function.

$\chi_{c, 9,95 \%}{ }^{2}=16.9$.

the nonloyal households give more importance to the possibility of obtaining gains than to suffering a loss. If a nonloyal customer becomes aware of a potential loss, he will change brands and purchase, for example, whichever alternative brand in being promoted at that particular time.
To sum up, we can affirm that the effect of losses is greater than the effect of gains for loyal consumers. The results obtained for nonloyal consumers do not, however, coincide in the two panels. As it is generally accepted that consumer characteristics can affect results obtained, one possible explanation of the phenomenon is that 
the composition of the national and regional panels do not have the same structure in spite of being random.

\section{The effect of households' consumption levels on brand choice}

Although loyalty has always been one of the main variables used to segment markets, it is not the only one. Allenby and Ross ${ }^{33}$ and Vázquez et al., ${ }^{23}$ for example, suggest considering consumption rate of the product category as a differentiating element between households.

Just as two groups - loyal and nonloyal were distinguished for loyalty, we will now establish two groups according to consumption level. This brings in a new variable, which will be called 'the consumption index', calculated using the following expression:

$$
I C_{j h}=\frac{N_{j h}}{C Q_{j}}
$$

where $I C_{j h}$ is the consumption index of product category $j$ (margarine) for household $h ; N_{j h}$ the number of consumed units of product category $j$ (margarine) for household $h$; $C Q_{j}$ the average consumed quantity of the product category $j$ (margarine) for all the households of the panel.

In order to detect if consumer behaviour varies according to this new variable, equation 2 is again considered for each of the segments (higher consumption than the mean and lower consumption than the mean) and for the two panels (national and regional). Table 7 summarises the results.

Analysis is similar to the one carried out for loyalty. The equation indicates differences between the two segments of households. Both panels surpass the critical value of the desired level of trust. Different brand choice behaviours according to consumption level can thus be confirmed.

In the national panel, the marginal effect of losses exceeds the gains effect for the households with lower consumption (Table 7). This is also the case for households with above average consumption. In the regional panel, households that consume less show some reaction to losses, while gains do not seem to have a significant effect on them. In households with higher consumption levels, the intensity of the gains surpasses the intensity of the losses. In this case, the regional panel does not support the consistency of the results obtained for the national panel. Despite this discrepancy, we can nevertheless defend the existence of different purchase behaviours between the households that consume more and those that consume less, since this is supported by our results. $\mathrm{H}_{4}$ as therefore been verified.

\section{SUMMARY AND DISCUSSION}

The present study has hopefully contributed to an understanding of brand choice behaviour by analysing the influence of prices, losses and gains, consumer loyalty and consumption level. Results obtained show that consumers are indeed influenced by price level. Using price as a starting point, consumers create expectations, compare, meditate and finally act. It has been proven that the observed price is compared with a reference price and from this comparison losses and gains arise, whose influence on brand choice has also been established.

The intensity with which consumers respond to losses and gains is different, that is effects are asymmetric. It seems that the loss response is more intense. In other words, when facing a loss or a gain of the same quantity, a reduced probability of choice as a consequence of a loss is greater than a gain-induced increased probability. The importance of this phenomenon must be considered explicitly in strategy and managerial performances. Activities that increase product value, such as gifts or the opportunity to take part in games or raffles, therefore need to be developed.

Since consumers are influenced by retailers' actions at the purchase outlet, it would be advisable to design and to develop a series of stimuli that help to increase the reference price. In this way, when the individual compares observed price and reference price, he is less likely to perceive a loss. Thus, for example, by increasing product advantage or quality, the consumers would perceive it as a better product 
Table 7: Model of brand choice for segments of consumption level

\begin{tabular}{|c|c|c|c|c|c|c|c|c|c|}
\hline \multirow[t]{2}{*}{ Variables } & \multicolumn{2}{|l|}{ Brand BO } & \multicolumn{2}{|l|}{ Brand B1 } & \multicolumn{2}{|c|}{ Brand B2 } & \multirow{2}{*}{$\begin{array}{l}\text { Global } \\
\text { signification }\end{array}$} & \multirow{2}{*}{\multicolumn{2}{|c|}{$\begin{array}{l}\text { Indicators of the model } \\
\text { adjustment }\end{array}$}} \\
\hline & $z$ & $\begin{array}{l}\operatorname{Exp} \\
(\beta) / 1-\operatorname{Exp}(\beta) /\end{array}$ & $z$ & $\begin{array}{l}\operatorname{Exp} \\
(\beta) / 1-\operatorname{Exp}(\beta) /\end{array}$ & $z$ & $\begin{array}{l}\operatorname{Exp} \\
(\beta) / 1-\operatorname{Exp}(\beta) /\end{array}$ & & & \\
\hline \multicolumn{10}{|c|}{ National panel } \\
\hline \multicolumn{10}{|c|}{ Small consumtion level } \\
\hline \multirow[t]{2}{*}{ Price } & -12.454 & 0.812 & 13.514 & 1.048 & 3.087 & 1.011 & 1866.483 & $\mathrm{LL}(\mathrm{c})$ & -5250.3962 \\
\hline & $(0.000)$ & 0.188 & $(0.000)$ & 0.048 & $(0.000)$ & 0.011 & $(0.000)$ & $\operatorname{LL}(\beta)$ & -3174.3458 \\
\hline \multirow[t]{2}{*}{ Gains } & 1.470 & 1.022 & -2.674 & 0.991 & -8.927 & 0.963 & 110.144 & Test RV & 4152.1008 (9 g.l.) \\
\hline & $(0.142)$ & 0.022 & $(0.008)$ & 0.009 & $(0.000)$ & 0.037 & $(0.000)$ & $\mathrm{Rho}^{2}$ & 0.3954 \\
\hline \multirow[t]{2}{*}{ Losses } & 5.038 & 1.262 & 10.619 & 1.069 & 9.484 & 1.062 & 149.958 & Rho²aj. & 0.3937 \\
\hline & $(0.000)$ & 0.262 & $(0.000)$ & 0.069 & $(0.000)$ & 0.062 & $(0.000)$ & AIC & 3183.3458 \\
\hline \multirow[t]{2}{*}{ Constant } & 9.937 & & -16.248 & & -4.139 & & & CAIC & 6432.0291 \\
\hline & $(0.000)$ & & $(0.000)$ & & $(0.000)$ & & & SBIC & 6423.0291 \\
\hline \multicolumn{10}{|c|}{ High consumption level } \\
\hline \multirow[t]{2}{*}{ Price } & -7.147 & 0.773 & 15.221 & 1.093 & 7.178 & 1.043 & 1194.262 & LL(c) & -2715.7879 \\
\hline & $(0.0009)$ & 0.227 & $(0.000)$ & 0.093 & $(0.000)$ & 0.043 & $(0.000)$ & $\operatorname{LL}(\beta)$ & -1491.7012 \\
\hline \multirow{2}{*}{ Gains } & 0.297 & 1.009 & -3.410 & 0.981 & -5.516 & 0.966 & 43.136 & Test RV & 2448.1734 (9 g.l.) \\
\hline & $(0.766)$ & 0.009 & $(0.001)$ & 0.019 & $(0.000)$ & 0.034 & $(0.000)$ & $\mathrm{Rho}^{2}$ & 0.4507 \\
\hline \multirow[t]{2}{*}{ Losses } & 2.564 & 1.300 & 4.108 & 1.035 & 4.561 & 1.040 & 16.138 & Rho²aj. & 0.4474 \\
\hline & $(0.010)$ & 0.300 & $(0.000)$ & 0.035 & $(0.000)$ & 0.040 & $(0.000)$ & $\mathrm{AIC}$ & 1500.7012 \\
\hline \multirow[t]{2}{*}{ Constant } & 5.632 & & -17.184 & & -8.849 & & & CAIC & 3060.9667 \\
\hline & $(0.000)$ & & $(0.000)$ & & $(0.000)$ & & & SBIC & 3051.9667 \\
\hline \multicolumn{10}{|c|}{$-2\left\{\operatorname{LL}\left(\beta^{\top}\right)-\left[\operatorname{LL}\left(\beta^{S}\right)+\operatorname{LL}\left(\beta^{H}\right)\right]\right\}=86.8296(9$ g.l. $)$} \\
\hline \multicolumn{10}{|c|}{ Regional panel } \\
\hline \multicolumn{10}{|c|}{ Small consumption level } \\
\hline \multirow[t]{2}{*}{ Price } & -4.452 & 0.850 & 3.825 & 1.040 & -3.563 & 0.959 & 97.368 & LL(c) & -273.0240 \\
\hline & $(0.000)$ & 0.150 & $(0.000)$ & 0.040 & $(0.000)$ & 0.041 & $(0.000)$ & $\mathrm{LL}(\beta)$ & -204.4691 \\
\hline \multirow[t]{2}{*}{ Gains } & -1.180 & 0.954 & -0.054 & 0.999 & -1.633 & 0.972 & 3.833 & Test RV & 137.1097 (9 g.l.) \\
\hline & $(0.238)$ & 0.046 & $(0.957)$ & 0.001 & $(0.103)$ & 0.028 & $(0.280)$ & $\mathrm{Rho}^{2}$ & 0.2511 \\
\hline \multirow[t]{2}{*}{ Losses } & 0.000 & $2.3 \mathrm{E}-10$ & -3.553 & 0.944 & -1.454 & 0.972 & 18.623 & $\mathrm{Rho}^{2} \mathrm{aj}$. & 0.2181 \\
\hline & $(1.000)$ & 0.999 & $(0.000)$ & 0.056 & $(0.146)$ & 0.028 & $(0.000)$ & $\mathrm{AIC}$ & 213.4691 \\
\hline Constant & 4.201 & & -4.248 & & 3.119 & & & CAIC & 467.2264 \\
\hline & $(0.000)$ & & $(0.000)$ & & $(0.000)$ & & & SBIC & 458.2264 \\
\hline High consu & nption level & & & & & & & & \\
\hline Price & -5.902 & 0.953 & 2.545 & 1.018 & -1.510 & 0.991 & 62.707 & LL(c) & -610.9410 \\
\hline & $(0.000)$ & 0.047 & $(0.011)$ & 0.018 & $(0.131)$ & 0.009 & $(0.000)$ & $\operatorname{LL}(\beta)$ & -508.4719 \\
\hline Gains & 5.627 & 1.073 & -0.633 & 0.989 & 1.686 & 1.017 & 43.154 & Test RV & 204.9382 (9 g.l.) \\
\hline & $(0.000)$ & 0.073 & $(0.527)$ & 0.011 & $(0.092)$ & 0.017 & $(0.000)$ & $\mathrm{Rho}^{2}$ & 0.1677 \\
\hline Losses & 4.294 & 1.071 & -1.309 & 0.983 & -1.467 & 0.984 & 24.517 & $\mathrm{Rho}^{2}$ aj. & 0.1530 \\
\hline & $(0.000)$ & 0.071 & $(0.191)$ & 0.017 & $(0.142)$ & 0.016 & $(0.000)$ & AIC & 517.4719 \\
\hline Constant & 2.903 & & -3.685 & & 1.331 & & & CAIC & 1081.3566 \\
\hline & $(0.000)$ & & $(0.000)$ & & $(0.183)$ & & & SBIC & 1072.3566 \\
\hline$-2\left\{\mathrm{LL}\left(\beta^{\top}\right)-\right.$ & $\mathrm{L}\left(\beta^{\mathrm{S}}\right)+\mathrm{LL}\left(\beta^{\mathrm{H}}\right)$ & \}$=80.5603$ (9 g.l. & & & & & & & \\
\hline
\end{tabular}

$\operatorname{LL}\left(\beta^{\top}\right)$ : likelihood function of the sample.

$\operatorname{LL}\left(\beta^{S}\right)$ : likelihood function of the sample for small consumption level.

$\operatorname{LL}\left(\beta^{H}\right)$ : likelihood function of the sample for high consumption level.

$\chi_{\mathrm{c}, 9,95 \%}{ }^{2}=16.9$.

and their reference price would be increased. For the same reason, it must be remembered that not all consumers react in the same way to the same information. Recommendations and strategies that can be useful for loyal consumers may be useless for the nonloyal ones, so the need to divide the market according to loyalty levels is patently clear. Similarly, households that consume more quantity of the product category do not behave in the same way as those that acquire the category of products only occasionally. In short, it is essential to seek out variables 
that help to group together consumers with like behaviours and tastes.

\section{Limitations and future research directions}

This research has hopefully contributed to explaining the process of brand choice by the consumer. Certain limitations must also be, however, recognised. First, it is limited by the type of models that were used. The conclusions drawn from these models are not autonomous: results are always offered as comparisons or taking one of the alternatives of the dependent variable as a benchmark. This greatly hinders the interpretation of the results and the resulting implications. Secondly, price elasticity has not been estimated. This would unquestionably have added accuracy and rigour to the study. Thirdly, there are other variables that have some influence on consumers' purchase behaviour. Rather than attempting to be comprehensive, this study sets out to establish a series of variables and to encourage the development of further related work.

Finally, in future research, new explanatory variables that help to improve our understanding of consumer purchase behaviour might be incorporated into the brand choice models. In this respect, some study of the influence of promotions - not only those based on price but also those that include gifts, participation in raffles, refunds or increased quantity of the product - would be helpful. Another major contribution to the issue might focus on sensitivity toward different marketing variables (price, reference price, losses and gains, promotions) as a function of other market segmentation alternatives, such as the importance of the purchase. We hope that the conclusions drawn here facilitate the development of strategies and the taking of decisions compatible with the necessities of the market.

\section{References}

1 Guadagni, P. M. and Little, J. (1983) 'A logit model of brand choice calibrated on scanner data', Marketing Science, Vol. 2, No. 3, pp. 203-238.

2 Lattin, J. M. and Bucklin, R. E. (1989) 'Reference effects of price and promotion on brand choice', Journal of Marketing Research, Vol. 26(Agosto), pp. 299-310.
3 Kalyanaram, G. and Little, J. (1994) 'An empirical analysis of latitude of price acceptance in consumer package goods', Journal of Consumer Research, Vol. 21, pp. 408-418.

4 Bell, D. R. and Bucklin, R. E. (1999) 'The role of internal reference points in the category purchase decision', Journal of Consumer Research, Vol. 26, pp. 128-143.

5 Han, S., Gupta, S. and Lehmann, D. R. (2001) 'Consumer price sensitivity and price thresholds,', Journal of Retailing, Vol. 77, pp. 435-456.

6 Mazumdar, T. and Papatla, P. (1995) 'Loyalty differences in the use of internal and external reference prices', Marketing Letters, Vol. 6, No. 2, pp. 111-122.

7 Monroe, K. (1992) 'Política de Precios', Mc Graw-Hill, Madrid.

8 Thaler, R. (1985) 'Mental accounting and consumer choice', Marketing Science, Vol. 4, No. 3, pp. 199-214.

9 Winer, R. (1985) 'A price model of demand for consumer durables; preliminary developments', Marketing Science, Vol. 4, No. 1, pp. 74-90.

10 Winer, R. (1986) 'A reference price model of brand choice for frequently purchased products', Journal of Consumer Research, Vol. 13, pp. 250-256.

11 Hardie, B. G. S., Johnson, E. J. and Fader, P. S. (1993) 'Modeling loss aversion and reference dependence effects on brand choice', Marketing Science, Vol. 12, No. 4, pp. 378-394.

12 Briesch, R. A., Krishnamurthi, L., Mazumdar, T. and Raj, S. P. (1997) 'A comparative analysis of reference price models', Journal of Consumer Research, Vol. 24, pp. 202-214.

13 Krishnamurthi, L., Mazumdar, T. and Raj, S. P. (1992) 'Asymmetric response to price in consumer brand choice and purchase quantity decisions', Journal of Consumer Research, Vol. 19, pp. 387-400.

14 Simonson, I. and Winer, R. S. (1992) 'The influence of purchase quantity and display format on consumer preference for variety', Journal of Consumer Research, Vol. 19, pp. 133-138.

15 Ailawadi, K. L., Neslin, S. A. and Gedenk, K. (2000) 'Pursuing the value conscious consumer: Store brands versus national brand promotions29th EMAC Conference. Marketing in the New Millennium, Rotterdam.

16 Mazumdar, T. and Papatla, P. (2000) 'An investigation of reference prices segments', Journal of Marketing Research, Vol. 35, pp. 246-258.

17 Bell, D. R. and Bucklin, R. E. (1999) 'The role of internal reference points in the category purchase decision', Journal of Consumer Research, Vol. 26, pp. 128-143.

18 Briesch, R. A., Krishnamurthi, L., Mazumdar, T. and Raj, S. P. (1997) 'A comparative analysis of reference price models', Journal of Consumer Research, Vol. 24, pp. 202-214.

19 Krishnamurthi, L., Mazumdar, T. and Raj, S. P. (1992) ‘Asymetric response to price in consumer brand choice and purchase quantity decisions', Journal of Consumer Research, Vol. 19, pp. 387-400.

20 Krishnamurthi, L. and Raj, S. P. (1991) 'An empirical analysis of the relationship between brand loyalty and consumer price elasticity', Marketing Science, Vol. 10, No. 2, pp. 172-183.

21 Bultez, A. (1975) 'Price cut versus coupon promotion: A comparative evaluation', No 75/100, European Institute for Advance Studies in Management, Brussels.

22 Simonson, I. and Winer, R. S. (1992) 'The influence of purchase quantity and display format on consumer preference for variety', Journal of Consumer Research, Vol. 19, pp. 133-138.

23 Vázquez, R., Santos, M. L. and Díaz, A. M. (1998) 'Decisiones de Selección de Marcas del Consumidor y Estimación de Precios de Referencia: Impacto sobre la Estrategia Detallista', Revista Española de Investigación y Marketing ESIC, Vol. 2, No. 2, pp. 117-139. 
24 Guadagni, P. M. and Little, J. (1983) 'A logit model of brand choice calibrated on scanner data', Marketing Science, Vol. 2, No. 3, pp. 203-238.

25 Kamakura, W. and Russell, G. (1989) 'A probabilistic choice model for market segmentation and elasticity structure', Journal of Marketing Research, Vol. 26, pp. 379-390.

26 Alvarez, B. (2002) 'El Proceso de Elección de Marca por el Consumidor. Incidencia de los Precios de Referencia y las Promociones', Doctoral Dissertation, University of Oviedo.

27 Bell, D. R. and Bucklin, R. E. (1999) 'The role of internal reference points in the category purchase decision', Journal of Consumer Research, Vol. 26, pp. 128-143.

28 Hardie, B. G. S., Johnson, E. J. and Fader, P. S. (1993) 'Modeling loss aversion and reference dependence effects on brand choice', Marketing Science, Vol. 12, No. 4, pp. 378-394.
29 Chapman, R. and Staelin, R. (1982) 'Exploiting rank ordered choice set data within the stochastic utility model', Journal of Marketing Research, Vol. 19(May), pp. 288-301.

30 Gensch, D. (1985) 'Empirical testing a disaggregate choice model for segments', Journal of Marketing Research, Vol. 22(November), pp. $462-467$.

31 Gensch, D. (1987) 'Empirical evidence supporting the use of multiple choice models in analyzing a population', Journal of Marketing Research, Vol. 29(May), pp. 197-207.

32 Gensch, D. and Javalgi, R. G. (1987) 'The influence of involvement on disaggregate attribute choice models', Journal of Consumer Research, Vol. 14, pp. 71-82.

33 Allenby, G. and Rossi, P. (1991) 'Quality perceptions and asymmetric switching between brands', Marketing Science, Vol. 10, No. 3, pp. 185-204. 